\title{
Revisiting the Mystery of Life in the Hereafter: Reflections of Fr Augustine Urayai of Zimbabwe
}

\author{
Misheck Mudyiwa \\ https://orcid.org/0000-0003-0783-4844 \\ University of Limpopo \\ fathermisheck@gmail.com
}

\author{
Sekgothe Mokgoatšana \\ https://orcid.org/0000-0002-3224-2341 \\ University of Limpopo \\ Sekgothe.Mokgoatsana@ul.ac.za
}

\section{Abstract}

The quest for knowledge regarding life after death is indispensable and paramount to most cultures and religions, including African spiritualties and mystery cults. Fr Augustine Urayai was a Roman Catholic priest and exorcist and this paper critically examines his theological reflections on death and life after death, particularly his idea of the "liminal/transitional phase" in the upward movement of spirits from earth to heaven for restoration and re-unification with God. The compulsory "liminal phase" or "zones" (magedhe) where all spirits pass through before their fate is ascertained comprises the resting, treatment, judgment, and feasting respectively. The article first examines the milieu in which Fr Urayai's theology emerged and developed. As a way of analysis, it explores the age-old question of the immortality of the soul and its link with other religions, cultural and philosophical traditions. As it probes deeper, the article critically examines the ramifications and impact of Fr Urayai's new theology on the Zimbabwe Christian landscape. The main argument developed in this article is that, even though Fr Urayai's theory of life in the hereafter appears to be a breakaway from celebrated mainstream theological formulations, it has the potential to hatch useful insights into possible new areas of theological reflection in the ongoing discourses on the link between Christian anthropology and different African spiritualties.

Keywords: death; life in the hereafter; zones; Fr Augustine Urayai; Catholic theology; African spirituality; Zimbabwe

\section{UNISA}

Studia Historiae Ecclesiasticae https://upjournals.co.za/index.php/SHE/index Volume 47 | Number 1 | 2021 | \#8602 | 18 pages https://doi.org/10.25159/2412-4265/8602 ISSN 2412-4265(Online)ISSN 1017-0499(Print)

(C) The Author(s) 2021 


\section{Introduction}

The question of the immortality of the soul took centre stage in the philosophical and theological literature of the medieval period. To date, in many religions and cultures, responses to questions regarding the mystique and mystery of death and life in the hereafter are diverse and heterogeneous. Ancient philosophers and theologians have vigorously wrestled with the enigma of life in the hereafter, but these academic luminaries have failed to agree or pin down with precision the incorruptibility or fate of the spirit/soul ${ }^{1}$ when it separates from the corruptible physical body. Interpretations regarding this paradox ${ }^{2}$ range from confirming that there is an afterlife, to denying completely the existence of life after death or the concept of unending existence that is celebrated in some world religions. For some religions and cultures, the belief in absolute annihilation of the soul after physical death is central. African traditional religions in particular, however, subscribe to the belief that the soul of the dead person enters into the ancestral world from where it stages a comeback to the physical world (Chukwuedo 2019). Thus, regarding the hereafter, "hundreds of creeds claim to be the dispensers of metaphysical truth, the first creed destroying what the second adores, and the third proclaiming as the simon-pure truth what the fourth condemns as abominable heresy" (Greber 1970, 6-7). Inasmuch as there is "cultural variation in beliefs about life everlasting" (Watson 2016, 455), a cursory survey of most cultures and religions, however, exhibits the basic belief that death opens doors to a higher form of life. These cultures and religions cling resolutely to the idea that some part of us human beings (and animals), at least survives death and destruction of the physical body. They believe and teach that the spirit somehow lives forever, with the ability to retain all the five senses, namely, hearing, smell, taste, vision and touch (Gelfand 1973).

Religions such as Christianity and Judaism (among others), for example, have significantly similar eschatological beliefs, particularly with regard to the hereafter and the Last Judgement (Revelations 20:11-13; John 5:29). However, contrary to their eschatological beliefs that the Last Judgement shall take place at the end of the world in dramatic fashion, preceded by catastrophic and cataclysmic events (Mandivenga 1983, 21), Fr Augustine Urayai advocated for particular or individual judgement that is preceded by a compulsory "liminal phase/zones" (betwixt) heaven and earth where spirits go before they are either sent to hell or restored back in heaven, their original home of bliss.

1 In this article, the words spirit and soul shall be used interchangeably.

2 Death is often referred to as paradoxical, simply because a number of religions and cultures across the world (particularly the Christian religion) teach that by losing life, one gains it in the beyond. 
As this article sets out to explore Fr Urayai's theological reflections on death and life in the hereafter, it has heavily relied on interviews. ${ }^{3}$ In this respect, parishes like Mutero (1967-1971, 1980-1990) and Chinyuni (1990-2003), where Fr Urayai worked as a disposer of demons for over two decades, proved essentially critical. Most of $\mathrm{Fr}$ Urayai's teachings with regard to both the "world in-between" (Milingo 1984) and the liminal phase were also recorded on tape by Alex Sibanda on 30 August 1994 (Mudyiwa 2016). Apart from interviewing Fr Urayai at his Chinyuni parish in Gweru Diocese before he succumbed to diabetes in 2003, on several occasions, one of the authors was privileged to witness and record some of Fr Urayai's healing sessions at both Mutero and Chinyuni parishes. The leading author also took the liberty of visiting many other mission stations outside Gweru Diocese where Fr Urayai conducted his healing sessions, in order to assess and examine the impact of his healing ministry in the Roman Catholic Church of Zimbabwe. Before making a critical appraisal of Fr Urayai's reflections on the hereafter that are rich in imagery, it is, therefore, necessary to first explore the clergyman's healing ministry upon which most of his eschatological beliefs find anchorage.

\section{Methodology}

Oral history has become a growing discipline and methodology to deal with narratives of previously marginalised people and their voices. Several scholars have popularised the craft of oral history in South Africa (Denis and Ntsimane 2008; Field 2001; 2007; 2012; Landman in Plaatjies-Van Huffel and Vosloo 2013; Lekgoathi 2009; Mokgoatšana 1998; 2019; 2020; Mathebula and Mokgoatšana 2018), to name but a few. Because dominant historical discourses are concerned with master narratives shaped by hegemonic discourses of power, oral history offers a fresh look at alternative discourses. As an alternative discourse, oral history examines topics and narratives that are often disregarded, or pushed to the periphery in favour of formal narratives entrenching establishments. Father Urayai's story is a narrative that disrupts those common, established canons and conventions, considering the time he began his healing escapades; when the Catholic Church in Zimbabwe and the world over had not embraced Africanisation and indigenisation as the core of its traditions. His courage in beginning a journey later to be considered acceptable, deserves a methodology that will be able to delve into experiences, emotions, opinions and feelings gathered from those who participated in or observed his teachings and healing exploits. For this reason, the article largely draws its material for analysis from interviews as both primary and secondary data. This paper uses oral history as both a method of data collection and analysis. Data for this paper were gathered through interviews, considered to be the chief instruments of oral historical methodology. As evidence for oral historical

3 During interviews, particular attention was paid to anonymity and confidentiality of most participants. Potentially identifiable informants have been treated in strict confidence or have been given pseudonyms. Where names of informants have been disclosed, prior consent would have been granted. The majority of interviewees whose names have been disclosed are mainly those who worked closely with Fr Urayai at various mission stations in his Gweru Diocese. 
methodology, attention will be given to anecdotes, snippets of memory and reflections which are key to understanding memory, and memorialisation of the past through the spoken word. Like all memory studies, the article has inclinations towards a life-history, manifesting in autobiographical reflections and representations. By autobiography, we include efforts of self-writing, de-scription, and representation as understood from the usual concepts of writing down a life; de-scribing (from scripto, script) and graphos (graphy). The article will, therefore, journey into a life, and describe the theological reflections of Father Augustine Urayai.

\section{Father Augustine Urayai (1931-2003)}

Augustine Paradza Urayai Madyauta was born in 1931 in Chilimanzi (now Chirumanzu) district in the Midlands province of central Zimbabwe. ${ }^{5}$ He was baptised a Catholic on 9 September 1941 at Holy Cross Mission in Gwelo (now Gweru) diocese. ${ }^{6}$ From 1937 to 1939, Augustine did his Sub A to Standard One (or Lower Primary) at Makanya Primary School. In 1940, upon the completion of his Standard One, he went for part of his Upper Primary (Standard Two up to Six) at Holy Cross Boarding School that was run by the Jesuits at that time. It was at Holy Cross Mission where Augustine and his friend, Leonard Mundure, became altar servers during the daily celebration of the sacrament of the Eucharist - an opportunity that is believed to have nurtured and watered his vocation to priesthood (Sibanda 1999; Mudyiwa 2016).

When the first group of minor seminarians enrolled at Chishawasha Major Seminary to study philosophy and theology in 1956, Augustine was one of the first three black seminarians to study for priesthood in Gweru Diocese. Of the three seminarians, namely, Kizito Mavima, Augustine Urayai and Francis Mugadzi, Augustine's road to priesthood was a tall order. His first real challenge came from none other than his biological father (David) who vehemently disliked the idea of his firstborn son becoming a priest, as it clearly meant that he (Augustine) was thus abrogating the culturally expected role to marry and perpetuate the family name. Even though Augustine had a bumpy road to priesthood, the period of his seminary formation endowed him with an unquenchable passion for a life of prayer and a deep desire for exorcism (Mudyiwa 2016, 29). It was also at Chishawasha Seminary where Augustine had access to literature that was outside his philosophical and theological curriculum. The same literature further watered and fanned his desire for exorcism. Having completed his philosophical and theological studies, which lasted for over seven years, at Chishawasha Seminary in Salisbury (now Harare), Augustine was ordained a Roman

4 This particular section on Fr Urayai's healing ministry is largely an extract from the author's report to the Vatican on the ramifications of Fr Urayai's healing ministry on the Roman Catholic Church in Zimbabwe.

5 Zimbabwe has a total of 10 provinces, namely, Bulawayo, Harare, Manicaland, Mashonaland West, Mashonaland Central, Mashonaland East, Masvingo, Matabeleland North, Matabeleland South and Midlands.

6 To date, Zimbabwe has a total of eight Catholic Dioceses, namely, the archdioceses of Harare and Bulawayo, and the dioceses of Gweru, Hwange, Mutare, Chinhoi, Gokwe and Masvingo. 
Catholic priest in 1964 at Gokomere Mission in Fort Victoria (now Masvingo) together with the other two pioneer local seminarians (Nyatsanza 1995).

After his priestly ordination at Gokomere Mission by Bishop Haene, Fr Urayai was first assigned to Mukaro Mission in Gutu district. After a short stint at Mukaro Mission, he was then moved to Mutero Mission in the same district in 1967. During his tour of duty at Mutero Mission, the ministry of healing and deliverance was largely dominated by some Shona Independent Churches of a charismatic and Pentecostal character, particularly Zionism which incorporated a number of traditional African beliefs. In the Roman Catholic Church then, there was still that silent, as yet inarticulate yearning for such a ministry of deliverance. The fact that most of the white fathers did not venture into exorcism could be that they were either suspicious of African independent churches, or they feared syncretism. As a young priest, Fr Urayai was, however, yearning to introduce such a ministry in his own Roman Catholic Church in order to curb the problem of double-dealing that was prevalent among his parishioners at Mutero mission. In times of serious illnesses, some of his parishioners would sneak out and request healing services from the tried and tested traditional healers or some African independent churches within their proximity (Tapiwa Mutero, Interview 12 April 2017).

Fr Urayai's dream came true when he had his inaugural case of healing in 1969. By then, he was just five years into his priestly ministry. Before Fr Urayai performed this particular inaugural case of healing, which subsequently acted as a watershed in his entire healing ministry, he first sought permission and approval from his local ordinary, Bishop Haene, as recommended by Canon Law (Canon 1151, 1152). After a successful exorcism, Fr Urayai then confidently asked for express permission from his bishop to offer healing and deliverance services, particularly within Gweru Diocese. When his request was granted, the Catholic clergyman thereafter became very popular for his healing sessions, to the extent that he became the best-known exorcist in the Roman Catholic Church of Zimbabwe at the time. A number of Catholics, particularly those who had interacted with him during his period of active ministry, unequivocally regarded him as a man of deep spirituality with an electric healing method (Shoko 2006).

Through interaction with spirits such as ancestral (midzimu), aliens (mashavi), lion (mhondoro), avenging (ngozi) and familiars (zvidhoma, zvituxwani or zvivanda), among others during his many healing sessions, over time, Fr Urayai developed a systematic healing method of pouring and splashing holy water on his patients and forcing these spirits to recite a Catholic prayer of contrition before setting free their victims (Tawanda Machawira, Interview 10 April 2017). He taught that evil spirits that made a perfect act of contrition, would be taken to paradise by God's planning angels and a new life (reincarnation) would then be planned for such at a time only known by these planning angels. Fr Urayai's unique healing method, captured by Sibanda (1999), Shoko (2006) and Mudyiwa (2016), comprised six main stages: exhortations; blessing of salt and water; drinking of blessed water; tying the victim with cords (in the case of violent 
victims/patients); challenging and casting out the evil spirits; and counselling the victim. Before setting their victims free, a number of such invading spirits would make several testimonies and confessions such as revealing their names, origins, operations, intentions and most importantly, their experiences in the "liminal phases" or zones (magedhe), particularly the decisive judgement zone. Inasmuch as the roles of midzimu are largely celebrated on the African landscape, Fr Urayai regarded all such spirits as evil and coming from the underworld (hell) where their master Satan rules. Thus, he repeatedly emphasised that midzimu come from hell, pretending to be angels of light simply to deceive the living and lead them to hell where they will reel under excruciating pain. He taught that midzimu are spirits of dead relatives who would have failed to make it to heaven (Fr Urayai, Interview 30 August 1994).

Based on such confessions and his extraordinary experiences as a disposer of demons, Fr Urayai subsequently took an uncompromising stance on some African traditional practices and spiritual belief systems. Thus, he often encouraged his patients and parishioners to desist from ancestral veneration, polygamy, divination, consulting traditional healers, beer drinking, smoking, and participating in spiritually-inspired traditional dancing, among other prohibitions based on African spiritualism. Abortion, divorce, same sex marriage, homosexuality and artificial birth control methods were also among proscribed practices (Chiedza Matanda, Interview 30 July 2017).

Daneel (1987) observed that in most prophetic movements, particularly on the African continent, the majority of prophetic office-bearers often testify to some dramatic encounters with the supernatural or the "hierophany" (Eliade 1957). Raymond Ogunade and Gbenga Zacheaus $(2018,130)$ contend that hierophanies are sacred, and are consecrated spaces of worship. As if to confirm Daneel's observation, on 12 June 1970, Fr Urayai asserted and professed that he had encountered an angel who spoke through Sylvester (1940-1981), his beloved catechist. The angel who used Sylvester as a deeptrance medium identified himself as Archangel Cherubim, ${ }^{7}$ one of God's Seven Archangels (Fr Urayai, interview 30 August 1994). This dramatic episode and other subsequent extraordinary experiences left an indelible impression on the otherwise sceptical, cautious and very Roman Catholic Fr Augustine Urayai and altered his dogmatic parochialism (Emmanuel Mupure, Interview 27 July 2014). Apart from demystifying the mysteries that surrounded the concept of death and life in the hereafter, or the immortality of the soul, the same celestial companion also at some later stages confirmed the existence of the four compulsory zones in the upward movement of spirits

7 Fr Urayai taught that Archangel Cherubim is the Judging Angel. God judges no one. In the order and hierarchy of creation, he comes third after Lucifer and Christ. It is critical to underline that the three Archangels mentioned in scripture and accepted traditional theology are Gabriel, Michael, and Raphael. The Archangel Cherubim is not one of the three Archangels usually listed. The Roman Catholic Church also seems to have recognised at various times nine orders or hierarchies of angels. The first hierarchy contains Seraphim, Cherubim and Thrones. The second contains Dominions, Virtues and Powers. The third hierarchy contains Principalities, Archangels and angels (Castro 2017). So, Archangel Cherubim and the idea of seven Archangels seems to be a concept unique and peculiar to Fr Urayai. 
from the earth, namely, resting, treatment, judgement and feasting. These angelic visitors repeatedly dictated to Fr Urayai the all-important answers to most fundamental questions about life in the hereafter, including humanity's pre-mortal existence as angels in heaven, the fall of angels, God's plan of salvation and the need for reincarnation. Fr Urayai's interactions with celestial beings, who communicated through human mediums for a period of 33 years (1970-2003), are documented by Mudyiwa in his Master of Philosophy thesis submitted to the University of Zimbabwe in 2016. His healing ministry and extraordinary experiences with angels subsequently culminated in the formation of an interdenominational prayer group referred to as the Light of Life Christian Group (LLCG) in Zimbabwe. To date, this new branch on Zimbabwe's ecumenical tree has a following of nearly 2000 believers, drawn largely from Zimbabwe's mainline churches and yet bound by the same ecumenical drive and belief systems. Ironically, members of the LLCG have no plans to secede and establish themselves as a separate entity, but simply to remain full members of their respective denominations and employ a unique "stay and reform from within" approach (Tapiwa Mubaiwa, Interview 15 October 2018).

\section{Fr Urayai's Theology of Death}

During his priestly ministry, Fr Urayai often taught his parishioners, LLCG members and his secret admirers that the death concept has varying meanings in various uses and contexts. Thus, he spoke of spiritual and physical death, atheism and spiritual indifference as the most common contexts (Alex Sibanda, Interview, 10 August 2019). During his active ministry as a Roman Catholic cleric in Gweru Diocese, Fr Urayai held firm to the belief that any form of separation from God is tantamount to spiritual death. For that reason, his eschatological teachings on spiritual death are largely premised on the biblical fallen angels (Revelations 12:1-17). The book of Revelations narrates a fierce war between two groups of angels - one third on the side of the dragon (Lucifer) and an unspecified number on the side of Archangel Michael and Christ. "Then war broke out in heaven. Michael and his angels fought with the dragon, and the dragon and his angels fought back. But he was not strong enough, and they lost their place in heaven. The great dragon was hurled down together with his angels" (Revelations 12:78). The Catechism of the Catholic Church (CCC 1994), frontline scholars on Sacred Scripture, as well as numerous other Christian traditions have documented stories about this pre-mortal celestial clash, but none has to date made any logical and clarion link of the fallen angels with humanity/mortals.

Fr Urayai taught that Revelations Chapter 12 describes an actual event in the pre-mortal existence of humanity. For him, pre-existence of humanity - as angels in heaven before the Great Fall - constitutes the most basic metaphysical truth underlying all knowledge of the beyond, a knowledge that is beyond both scientific myths and scientific facts ( $\mathrm{Fr}$ Urayai, Interview 30 August 1994). He believed that human life does not begin at

8 In the Gospel of Luke, Jesus confessed that he was an eyewitness to this pre-mortal celestial battle. "I watched Satan fall from heaven like lightening" (Luke 10:18). 
conception but with pre-mortal existence. Thus, for him, the first spiritual death was suffered by none other than the biblical fallen angels who committed the sin of apostasy and got expelled out of heaven. For Fr Urayai, the sin of apostasy is the actual original sin, not the Adamic guilt (Genesis 3:1-24). It is the sin of the world referred to in the Gospel of John (1:29). Paul also alluded to this compulsory sin when he underlined that all have sinned and fell short of the glory of God (Romans 2:23). Fr Urayai taught that God put in place the Great Plan of Salvation after the fall of a third of heaven's total population to enable the "spiritually dead" fallen angels to re-unite with Him once more. He created the earth. As per plan, Jesus was the Saviour and those who followed the plan would come to earth or testing ground to experience mortality and progress toward eternal life. Gnostic teachings ${ }^{9}$ also allude to an almost similar eschatological deduction:

From the supreme concealed God, living in an inaccessible realm of light, the universe has been created by emanations in such a way that numerous spirits have emerged from this God and receded farther and farther from their divine origin. The wider the distance grows, the more they lose their essence and the less light they possess. On the last and lowest step they finally merge with matter which belongs to the empire of darkness and evil.... Salvation now consists of the liberation of the divine sparks from matter and their return to the realm of light (Pleroma) of the supreme God ... Christ's task was to reveal the so far unknown supreme God to men and to teach them how one can separate from matter, surmount darkness, and return to the Pleroma of God. (Franzen 1969, 3940)

Thus, for Fr Urayai, human beings are incarnations of the same numerous spirits that receded farther and farther from their divine origin. Apparently, they are currently participating in God's Ogplan of salvation to effect their gradual ascent back to heaven. From hell, where he and his "spiritually dead" angels are sequestered, Lucifer, however, continues to forcefully rebel against God's most fancied plan of salvation and employs varied altered plans that negate the urgency of God's Great Project (Vimbai Marega, Interview 30 August 2017). Fr Urayai taught that atheism, breaking the Ten Commandments, spiritual indifference, abortion, family planning, homosexuality, same sex marriages, divorce, among other practices, are Lucifer's plans to sabotage, slow down or even reverse God's plan of salvation. Thus, to the man who wanted to first bury his father, then come and follow him, Jesus replied: "Follow me, and leave the dead to bury their dead" (Matthew 8:22). Fr Urayai emphasised that this passage implies that the spiritually dead, atheists and those who are spiritually indifferent cannot preach the Gospel and advance God's kingdom (Fr Urayai, Interview 30 August 1994).

\section{Physical Death and the Upward Movement of Spirits}

Fr Urayai underscores that physical death is basically the separation of the material body and the spirit at the end of earthly life; whereby the body goes back to dust and the spirit goes to heaven for judgment. Whereas the separation of body and spirit indicates

9 During his training at Chishawasha seminary, Fr Urayai was probably exposed to Gnostic thinking as part of Roman Catholic theological training on the defence of orthodoxy. 
physical death, the separation of the spirit from God, especially after judgement, is regarded as spiritual death or second spiritual death (Revelations 21:8). This separation of body and spirit is inevitable because the days of each person are fixed by the Creator (Job 14:5). Fr Urayai underlined that death comes about when God's planning angels cut or snap from a living person what he referred to as the spiritual "silver cord" 10 that connects or joins the spirit and the material body. He emphasised that once the silver cord or thread is snapped by the responsible spiritual masters, nothing can bring back to life the lifeless body, even God Himself, because it is one of God's universal and eternal spiritual laws. For Fr Urayai, cutting or severing of the silver cord goes beyond any scientific verification (Fr Urayai, Interview 30 August 1994).

Upon the completion of the material life, when the silver cord is cut by the planning angels, the spirit of the deceased begins a long spiritual purification journey and process. The duration of the journey differs from person to person, depending on the type of life each lived on earth (Shoko 2006). It is shorter for those who lived a good/virtuous life and longer for those who lived an unrepentant, immoral and unforgiving life. For the virtuous, a team of celestial beings, comprising guardian angels, deceased relatives (already in heaven) and many other spirit friends, are sent by God to give escort to the returning spirit. The spiritual journey may take several weeks, months, or even years for a spirit to reach its initial intended destination, the zones.

\section{The Four Zones}

As earlier underlined, before their final reunification and repatriation back to heaven, spirits of the deceased have to pass through four zones (Magedhe), namely; resting, treatment, judgement and feasting. Shoko (2006) and Sibanda (1999) also confirm the four separate zones. In an interview with Fr Urayai, he underlined that the resting zone, which happens to be the first zone, enables the spirit to rest and get used to the spiritual laws and environment, as well as taking a rest from the tiresome earth-heaven journey. Since the earth is a place of suffering, pain and spiritual bruises (Shoko 2006), all the illnesses that the body suffers torment the spirit as well. If the physical body is wounded and tired, the spirit is wounded and tired as well, and thus, it requires some rest. Hence, the resting zone re-energises and re-vitalises the weak and ailing spirit. The period of resting normally varies from spirit to spirit, depending on the level of spiritual development of each spirit at the time of death. It may be longer for atheists and those who were spiritually indifferent. When the resting time is over, the spirit enters the second zone.

Fr Urayai emphasised that spirits that have rested enough in the first zone are taken to the treatment zone where they are treated by the healing angels who, perhaps, fall under

10 Ecclesiastes 12:6 makes reference to the Silver Cord. In metaphysical studies and literature, it is known as a life thread or a life-giving linkage that joins or connects the physical body to the etheric (spiritual) body. 
Archangel Raphael (the medicine of God). ${ }^{11}$ The treatment zone is some kind of a spiritual hospital where visiting spirits or new-comers (heaven or hell bound) are energised by celestial nurse aids with spiritual energy or odic force, which is God's spiritual healing power (Fr Urayai, Interview 30 August 1994). This kind of treatment is said to be necessary and compulsory because when the body is frail and feeble, the spirit is also said to suffer the same. Hence, the need for hospitalisation to ensure swift spiritual healing and recovery. Fr Urayai mentioned that there are, however, cases whereby some spirits refuse to comply and remain adamant insisting that they want to "lodge" in the resting zone, waiting for the sound of the trumpet. Situations of this nature are most common with spirits from members of those religions, churches or denominations that teach such a theology on earth. Thus, under these circumstances, planning angels are left with no option except to plan another life for such stubborn and adamant spirits and make sure they are born in a family that upholds proper belief systems. Reincarnation for such spirits may take place before they even enter the judgement zone. Through his experiences as an exorcist, Fr Urayai established that after passing through the first and second zones, particular judgment is passed on each person or spirit without delay, fear or favour (Fr Urayai, Interview 30 August 1994).

Both the resting and treatment zones mentioned above make the spirit strong and fit for zone three, which is reserved for judgment. This is the decisive zone that separates "sheep" from "goats" (Matthew 25:31-36) and is the most feared zone as well. Judging angels who are under the leadership of Archangel Cherubim are in charge of this most feared zone. All authority to judge squarely rests upon Archangel Cherubim (Fr Urayai, Interview 30 August 1994). During his priestly ministry, Fr Urayai taught that God judges no-one. From the private revelations that he got from his protracted interaction with Archangel Cherubim, it was revealed that in the judgment zone, a video is simply shown to the visiting spirit in the presence of other angels and departed relatives who would have already found their places in heaven. ${ }^{12}$ In that spiritual "theatre," the video recounts the person's activities during his/her life on earth and it is upon these life scenes that judgment is based. However, all confessed sins do not show on the video tape (Shoko 2006). One's actions towards neighbours are critical in the judgment zone (Matthew 25:42-46). Thus, those people who would have loved their neighbour on earth have mercy shown upon them, while atheists and those who were spiritually indifferent are condemned and sentenced. The same applies to those who actively participated in negating the urgency of God's plan of salvation in any way during their earthly lives. Any spirit that fails to make it in the judgement zone is sent to hell where it will reel

11 In the book of Tobit (12:15), an angel by the name of Raphael revealed his identity to Tobias and declared: "I am Raphael, one of the seven angels [perhaps archangels] who stand ever ready to enter the presence of the glory of the Lord."

12 Manifestations of countless cases of (evil) spirits that failed the video test also confirmed this unusual phenomenon of the video test during Fr Urayai's healing sessions particularly at Mutero and Chinyuni Missions. 
under excruciating pain, waiting for its next reincarnation (Makomborero Chamisa, Interview 10 September 2018).

Spirits that pass the video test will proceed to the fourth and final zone for a test of the messianic banquet. It is in the fourth zone where celebrations, eating and drinking in the company of saints, angels and departed relations take place. After the celebrations, the successful spirits would then proceed to their allotted dwelling places and re-join innumerable angels that did not participate in the pre-mortal battle that subsequently led to the fall of a third of heaven's total population (Fr Urayai, Interview 30 August 1994). Thus, contrary to the position held by other denominations that the spirit will one day be reunited with the body at the Final Resurrection, Fr Urayai maintained the position that there is no such thing as resurrection of the human body. Instead, he underscored that the body returns to dust from where it came, and the spirit returns to God, its creator (Ecclesiastes 12:7). For this reason, Fr Urayai often discouraged his parishioners from mourning at funerals, arguing that it is pointless to mourn and cry when angels in heaven are rejoicing and celebrating the return of a one-time deserter of the beatific vision. Thus, the dramatic resurrection of Ezekiel's dry bones (Ezekiel 37:1-14) in its literal interpretation has, therefore, no place in Fr Urayai's theology of death and life in the hereafter.

\section{Reception of Fr Urayai's theology}

In spite of his ground-breaking experiences on death and the afterlife, Fr Urayai's conceptualisations ironically brought some seemingly irreconcilable controversies and heated debates within the Roman Catholic Church circles. Like his controversial Zambian and Tanzanian counterparts (Bishop Milingo and Fr Nkwera ${ }^{13}$ ), Fr Urayai was labelled a heretic by one of his bishops and on several occasions asked to stop his healing ministry and recant his theology that was not in conformity with the Catholic Church. In 1978 he was suspended for his controversial healing ministry. Due to public pressure, he was, however, called back and posted to Mutero Mission (Sibanda 1999, 12). During his tour of duty at Mutero Mission, Fr Urayai ignored both the stigma and voices of criticism and continued to teach and exorcise clandestinely. He often argued that obedience to superiors is a noble thing but absolutely nothing can beat or defeat what he experienced. He believed that "the only source of knowledge is experience" (Albert Einstein). Thus, against all odds, guided by his extraordinary experiences, his ministry continued for over three decades until he succumbed to diabetes in 2003, after battling the disease for about four years. Whereas the disease put an abrupt end to his active ministry, his departure marked the beginning of persecutions, suspensions,

13 Both Bishop Milingo and Fr Felician Nkwera are controversial characters in their respective countries. The Zambian former Archbishop Milingo stepped down from his position in 1983 after Rome criticised his exorcism and faith healing practices. He later got married in 2001 and established his own congregation of married priests in July 2006. On 24 September 2006 he consecrated four men as bishops without papal approval. In Tanzania, for many years, Fr Nkwera's controversial Marian Faith Healing Movement has been offering Catholic healing rituals under the patronage of the Virgin Mary. Exorcism and a special water service are at the centre of their healing process. 
sanctions and interdicts for the upholders of his theology, particularly his LLCG congregation (LLCG informant, 20 January 2015).

Within the Roman Catholic Church, LLCG is nicknamed "Super Roma," implying that it is viewed as a heretical breakaway sect. For that reason, the movement faced fierce criticism from several Christian quarters, particularly the Catholic Church. In their collective Pastoral Statement of 7 December 2005, the Zimbabwe Catholic Bishops' Conference (ZCBC 2005) denounced LLCG as a sect that is not in communion with the Roman Catholic Church, practically and doctrinally. In the same letter, the bishops also strongly advised Catholics, religious and the lay faithful, against participating in any activities of LLCG or upholding their belief system. However, against all odds, LLCG has thrived unabated. In spite of several voices of criticism, it has managed to recruit from Zimbabwe's mainline churches, including a handful of priests and nuns from the Catholic and Anglican churches. These religious men and women continue to offer their services clandestinely to the LLCG. For disobeying his superiors who frowned at his controversial healing ministry in the Diocese of Gweru, Fr Urayai paid the ultimate price. He was never appointed priest in charge of any Catholic Mission in Gweru Diocese in his entire priestly ministry. For a period of 39 years, Fr Urayai served and finally died as an assistant priest (Mudyiwa 2016). For him, it was, however, a blessing in disguise because with fewer administrative responsibilities as an assistant priest, he had ample time to perform his healing sessions, nourish and reinforce his new religious movement. To date, his teachings are more popular among the laity than his fellow clerics. Those who only read about him continue to wonder what sort of man he was, around whom such controversy raged within the Catholic Church in Zimbabwe today. At this point, it is critical to make a brief analysis of the concept of the hereafter in order to situate Fr Urayai's theology of death and life in the hereafter.

\section{Analysis}

Scholarly discussions of afterlife beliefs cover a broad range of academic disciplines such as philosophy, religious studies, anthropology and psychology (Hodge 2002, Miller 2014). A comprehensive survey and examination of world religions and cultures reveals that the concept of life in the hereafter is thus, a shared eschatological teaching. However, without real proof of a "visible" survival of the person after death, most religions and cultures believe in an immortal soul, spirit or ghost that continues to live in some form, after death. In spite of their variations and seemingly irreconcilable theological differences with regards to other theological concepts, religions such as Christianity, Islam, Judaism, Hinduism, Buddhism, Zoroastrianism and Bahai Faith teach that after death, a soul within us leaves the body and lives on for eternity. The teaching is not only basic and central among such religions of the world, but with some minor and sometimes serious variations, the teaching is also central and indispensable among the native and tribal religions throughout the vast continent of Africa (Mbiti 1975, Gelfand 1973). Within Fr Urayai's theological reflections, his new dimension of 
life in the hereafter has attracted the attention of academic scholars and is pressing into view for academic discussion and discourse more than ever before.

Philosophical discussions of the afterlife date back to Pythagoras (ca $570 \mathrm{BC}$, ca 490 BCE) and Plato (c 428-348 BCE), both of whom argued for the transmigration of the soul (Hodge 2002). These and many other Greek philosophers such as Socrates (469399 BCE), Aristotle (384-322 BC), Epicurus (341-270 BC) had a profound influence on the Jewish system of thought and all the Church Fathers, from Justin (100-165 AD) to Augustine (354-430) AD. In ancient Western philosophy, Plato affirmed a pre-natal life of the soul and the soul's continued life after death. With the rise of Christianity in the West, discussions concerning the afterlife centred on how personal identity was maintained in the afterlife in view of the doctrine of the resurrection of the body (Daniel 12:13; John 6:40; John 11:24; 2 Timothy 2:11). Ironically, in the ancient Hebrew philosophy, the concept of heaven and hell was limited to an underworld development (Psalm 88:3-5). Contemporary discussions about the afterlife have, however, shifted and focused on the possibility of disembodied existence and how this is to be understood. Recent research in the cognitive science of religion has also suggested that humans intuitively believe that others survive death (Hodge 2011, 395). Thus, variations with regards to afterlife beliefs are diverse and heterogeneous. Pivoting on the power of private revelations, Fr Urayai has also joined the seemingly endless debate about life in the hereafter and advanced the theory of a compulsory "liminal/transitional phase" in the upward movement of spirits from earth to heaven for restoration and re-unification with God.

Fundamentally, Christian beliefs about the afterlife are essentially based on the resurrection of Jesus Christ (Matthew 28:1-8; Mark16:1-8; Luke 24:1-8; John 20:110). Jesus promised that everyone would be raised from the dead and then will be judged (John 5:28-29). On the day of the resurrection, good people are rewarded with eternal life, but evil people are punished (Proverbs 10:16-26; Matthew 7:21-23; Revelations 21:8). Ironically, the scriptures are, however, silent about the concept of Fr Urayai's resting, treatment, judgement and feasting zones. Though informative and logical, the fact that Fr Urayai's theology of death and life in the hereafter is essentially based on his private revelations, is one potential area of clash with his Roman Catholic Church.

Whilst Fr Urayai's mother church, the Roman Catholic Church, believes in both public and private revelation, she is cautious in her approach with regard to both. The church teaches that public revelation was completed through Christ (Catechism of the Catholic Church 1994), and therefore, was concluded with the death of the last apostle (Dei Verbum, 4); yet private revelation has continued to date in some Catholic/Christian circles. The Catholic Church thus confirms that numerous private revelations have been documented throughout the history of Christianity and a lot more are yet to be documented. The tradition of the Christian Church exhibits such claims. However, documented or undocumented, the church teaches that private revelations (like that of Fr Urayai) do not belong to the deposits of faith. They do not improve or complete 
Christ's definitive revelation. For that reason, the Christian faith does not "easily" accept revelations that claim to surpass or correct, improve or complete public revelation (Catechism of the Catholic Church 1994). Thus, following the same logic, the church underlines that while public revelation is binding on all Christians, private revelations are only binding on those who receive them and may not be propagated or disseminated. In the same vein, the church does not subscribe to the practice of spiritism or mediumship either, let alone to the doctrine of seven archangels, as taught by Fr Urayai. In fact, the church teaches that there are only three archangels, namely, Gabriel, Michael and Raphael. She also underlines that spiritism or mediumship, upon which Fr Urayai's revelation oscillates, often implies divination or magical practices and for that reason, the church warns the faithful against it (Catechism of the Catholic Church 1994).

As a Catholic minister of religion, by articulating a theory of the liminal phase, which has no solid biblical support, and which is essentially incompatible with the Christian (particularly Catholic) doctrine of the resurrection of the dead, Fr Urayai may be accused of undermining the two Catholic governing codes, namely Canon Law (1983) and the Catechism of the Catholic Church (1994). The two codes are the traditional deposits of Catholic articles of faith. They both stipulate that official Catholic doctrine embodies the authoritative understanding of the faith taught by Jesus and that the Holy Spirit protects the church from falling into error when teaching these doctrines. Thus, the two governing codes are sacrosanct. In view of the fact that on the one hand Fr Urayai's theology of life in the hereafter may find it difficult to find a niche in orthodox theology; on the other hand, the Catholic clergyman has, however, created a unique and perfect opportunity for the Zimbabwe Christian populace to observe how African and home-grown theologians handle Christian theology and the Gospel, outside the immediate spheres of Western-oriented historical churches and structures, particularly the Vatican.

To this effect, it is critical to underline that traditional Christian theology is continually confronted with new theology and insights from various disciplines, including history, missiology, theology and African Christianity (among others); which is reflective of the fact that the debate and discourses on the link between Christian anthropology and emerging African spiritualties still rage on. In today's world, it is hard to say that any particular denomination, culture or philosophy has all the answers to every other fundamental question of the beyond. The days when most people expected the church or tradition to give answers that cut across all academic disciplines, are long gone. The church exists in time and history that continue to explore, evolve and transform. That being the case, it is an undeniable fact that while many believe in the sacrosanctity of tradition, particularly with regards to the doctrine of the hereafter and immortality, in its broad sense, tradition is never fixed or immutable. Logic, wisdom and personal experience do concur that tradition can sometimes be questioned, modified and even repudiated if deemed necessary. Fr Urayai's reflections on death and life in the hereafter, are, therefore, a representation of essential steps towards an African Christian independence from conventional theology and Vatican dominance. Inherited from 
medieval debates and continuing well into the 21 st century, the debate regarding the corruptible nature of the body and the incorruptible nature of the soul is, therefore, far from over.

\section{Conclusion}

The article has explored Fr Urayai's perceptions of death and life in the hereafter, which largely reflect the dynamics and dialects of African Christianity. Among many other things, the article has established that Fr Urayai's theology of life in the hereafter does not bear the marks of his genius, but is ostensibly the result of private revelations and dictations from the spirit world, an element that may (or may not) favour its advancement on the African landscape. Even though the concept of the liminal phase is peculiar only to him, the doctrine according to which the soul of the dead separates from the body at death and carries on with immortality in either heaven or hell, is not a Christian innovation. From a philosophical study of religions and cultures, it is unanimously accepted that the doctrine in its classical settings was articulated by Socrates and Plato, who in turn had a lasting and monumental influence on other religions and cultures, and perhaps on Fr Urayai as well. Thus, the great majority of Christian philosophers, down to St Augustine, were Platonists by design. By adhering to the doctrine of pre-existence and immortality of the soul, Fr Urayai has some visible Platonic residues in his blood. While the mere concept of immortality may be accepted without question, some of his reflections, particularly the concepts of pre-existence of the soul, the four zones and reincarnation (among others), may have difficulties in finding a niche in the traditionally accepted Christian theology. However, even though his "experience-based" perceptions appear like a break-away from biblical and mainstream theology, they have the potential to hatch useful insights into possible new areas of theological reflection. His perceptions of death and life in the hereafter may also contribute significantly to the ongoing discourses on the link and affinity between Christian anthropology and different African spiritualties.

\section{References}

Chukwuedo, M. U. 2019. "A Comparative Study of the Immortality of the Soul in Christianity and African Traditional Religion." A New Journal of African Studies Vol. 15: 52-63. https://doi.org/10.4314/og.v15i1.3.

Castro, R. 2017. "Hierarchy of Heaven.” Online: medium.com/arcanablog/hierarchy-ofheaven-34fd25af5795.

Daneel, I. 1987. Quest for Belonging. Gweru: Mambo Press.

Denis, P., and R. Ntsimane (Eds). 2008. Oral History in a Wounded Country: Interactive Interviewing in South Africa. Scottsville: University of KwaZulu-Natal.

Eliade, M. 1957. The Sacred and the Profane: The Nature of Religion. New York: Harper and Row Publishers. 
Field, S. 2001. "Remembering Experience, Interpreting Memory: Life Stories from Windermere." African Studies 60 (1) 119-133. https://doi.org/10.1080/00020180120063656.

Field, S. 2007. “Oral History Methodology.” South-South Exchange Programme for Research on the History of Development.

Field, S. 2012. Oral History, Community and Displacement: Imagining Memories in Postapartheid South Africa. Springer. https://doi.org/10.1057/9781137011480_1.

Franzen, A. 1969. A Concise History of the Church. New York: Burns and Oates.

Gelfand, M. 1973. The Genuine Shona: Survival Values of an African Culture. Gweru: Mambo Press.

Greber, J. 1970. Communication with the Spirit World of God: Personal Experiences of a Catholic Priest. Teaneck: Johannes Greber Foundation.

Hodge, K. M. 2002. Afterlife. Belfast: Queens University.

Hodge, K. M. 2011. "Why Immortality alone will not Get me to the Afterlife." Philosophical Psychology 24 (3): 395-410. https://doi.org/10.1080/09515089.2011.559620.

Landman, C. 2013 "Remembering Feminist Theology in South Africa, 1960-1990." In Reformed Churches in South Africa and the Struggle for Justice: Remembering 19601990, edited by Mary-Anne E. Plaatjies-Van Huffel, and R. Vosloo. Stellenbosch: Sun Press.

Lekgoathi, S. 2009. “'Colonial' Experts, Local Interlocutors, Informants and the Making of an Archive on the 'Transvaal Ndebele,' 1930-1989." Journal of African History. Cambridge University Press, 61-80. https://doi.org/10.1017/S0021853708003976.

Mandivenga, E. C. 1983. Islam in Zimbabwe. Gweru: Mambo Press.

Mathebula, M. D., and S. Mokgoatšana. 2018. "Reconstructing Changamire's Family Roots: New Evidence from Valoyi Oral History." New Contree Vol. 81 Dec 2018. ISSN No. 0379-9867.

Mbiti, J. S. 1975. Introduction to African Religion. London: Heinemann Educational Books.

Milingo, E. 1984. The World in between: Christian Healing and the Struggle for Survival. London: Orbis books.

Miller, L. 2014. "Beyond Death: The Science of the Afterlife." Online: time.com/68381/beyond-death-the-science-of-the-afterlife- 2 . 
Mokgoatšana, S. 1998. “It's her story too.” Southern African Journal for Folklore Studies 9 (2): $1-12$.

Mokgoatšana, S. 2019. "Of Prophecies Mythmaking and Martyrdom in the Manche Masemola Narrative: I Will Be Baptised in my Blood.” Studia Historiae Ecclesiasticae Vol 45 (2).

Mokgoatšana, S. 2020. "Controversial Contradictions in the Testimonies of Manche Masemola: The Challenge of Variability in Oral History." Studia Historia Ecclesiasticae 46 (1): 1-21.

Mudyiwa, M. 2014. "Decades of demon fighting in the Roman Catholic Church in Zimbabwe: Pioneers vis-à-vis Canon Law: Experiences of Fr Augustine Urayai." International Journal of Humanities and Social Studies Vol. 2: 196-206.

Mudyiwa, M. 2016. “An Investigation into the Impact of Super Roma’s Healing Ministry in the Roman Catholic Church in Zimbabwe: A case Study of Gweru and Masvingo Dioceses.” Unpublished Master of Philosophy Dissertation. Harare: University of Zimbabwe.

Nyatsanza, W. 1995. Called by Name. Gweru: Mambo Press.

Ogunade, R., and G. Zacceaus. 2018. "Hierophant and Hierophany in Yoruba Spirituality: OriOke Ajaforunte in Egbe, Nigeria, as a Case Study." In Ori-Oke Spirituality and Social Change in Africa: Contemporary Perspectives, edited by Soede Nathanael Yaovi, Patrick U. Nwosu, Akiti G. Alamu, Lemuel E. Odeh \& A. Y. Mohammed. Mankon, Bamenda: Langaa Research \& Publishing CIG. https://doi.org/10.2307/j.ctvh9vtpk.12.

Paul, V. I. 1965. Dei Verbum: The Second Vatican Council's Dogmatic Constitution on Divine Revelation.

Shoko, T. 2006. "Super Roma: Towards a New Theology of Healing in the Roman Catholic Church in Zimbabwe.” Swedish Missiological Themes Vol. 94: 349-369.

Sibanda, C. 1999. "An inquiry into the Ministry of Fr Augustine Urayai." Unpublished BA Honours Dissertation. Harare: University of Zimbabwe.

Watson, R. E. 2016. "Does the Body Survive Death: Cultural Variation in Beliefs about Life Everlasting." Cognitive Science: A Multidisciplinary Journal Vol. 41: 455-476. https://doi.org/10.1111/cogs.12430.

The Catechism of the Catholic Church. 1994. Nairobi: Pauline Publications.

The Code of Canon Law. 1983. London: Collins Liturgical publications.

The Jerusalem Bible. 1966. London: Darton, Longman and Todd. 
The Zimbabwe Catholic Bishops' Conference. 2005. "Public Associations of Christ's Faithful vis-a-vis Sects like the Light of Life Christian Group or Supa Roma.” Pastoral Letter, December 2005.

\section{Interviews}

Chamisa Makomborero, 10 September 2018. Interview, Mutero Mission.

Machawira Tawanda. 10 April 2017. Interview, Mutero Mission.

Marega Vimbai. 30 August 2018. Interview, Mutero Mission.

Matanda Chiedza. 30 July 2017. Interview, Chinyuni Mission.

Mubaiwa Tapiwa. 15 October 2018. Interview. Chinyuni Mission.

Mupure Emmanuel. 27 July 2014. Interview, Harare.

Mutero Tapiwa. 12 April 2017. Interview, Mutero Mission.

Sibanda, Alex. 10 August 2019. Interview, Redcliff Town.

Urayai, Augustine. 30 August 1994. Interview, Redcliff Town. 